Agnieszka Makarewicz-Marcinkiewicz

Uniwersytet Wrocławski

\title{
Projektowanie innowacyjnych inwestycji społecznych na poziomie ponadnarodowym
}

DOI: $10.19195 / 1643-0328.23 .8$

Słowa kluczowe: innowacyjne inwestycje społeczne, efektywność projektów społecznych, ponadnarodowa polityka społeczna

\section{Wprowadzenie}

W literaturze przedmiotu funkcjonują definicje innowacji społecznych, które wprowadzają podział na różne poziomy implementacji: mikro (sprowadzony do innowacji socjalnych), mezzo (innowacje społeczne) i makro (systemowe). Taki podział budzi jednak szereg wątpliwości natury przedmiotowej (Dlaczego na poziomie mikro innowacje dotyczą sfery socjalnej?) oraz co do zasięgu terytorialnego (Czy powinien obejmować system państwowy, ponadnarodowy itp.?).

Według autorki, zjawisko jest innowacją społeczną, kiedy stanowi trwałą zmianę systemową, wprowadzającą nowe rozwiązanie konkretnej kwestii lub problemu społecznego, ukierunkowaną na rzeczywiste potrzeby społeczne zidentyfikowane na poziomie lokalnym, regionalnym lub narodowym. Najczęściej opisywanymi innowacjami społecznymi są te dotyczące nowych płaszczyzn lub innowacyjnych form współpracy oraz lepszego wykorzystania zasobów.

W niniejszym opracowaniu innowacje społeczne zostały przedstawione z perspektywy projektu Innovative Social Investment: Strengthening Communities in Europe, InnoSI (Innowacyjne Inwestycje Społeczne: wzmacnianie wspólnot europejskich) ${ }^{1}$ realizowanego w ramach programu Horizon 2020-EU.3.6. Koordynatorem całego projektu jest Uniwersytet Metropolitalny w Manchesterze, a partnerem Uniwersytet Wrocławski. Udział autorki sprowadzał się do identyfikacji i analizy sygnałów lokalnych w zakresie innowacji społecznych oraz roli eksperta w zadaniu szóstym: From foresight to welfare practices: scenario planning (Od przewidywania do praktyk socjalnych: planowanie scenariuszy), które było ukierunkowane na ustalanie trendów w polskiej, a także europej-

\footnotetext{
${ }^{1} \mathrm{Nr}$ projektu 649189.
} 
skiej polityce społecznej. Koordynatorem zadania szóstego był zespół z Uniwersytetu Nauk Stosowanych (University of Applied Sciences) w Turku (Finlandia). Perspektywa czasowa projektu to 10 lat (od roku 2017).

Badania w zamierzeniu miały zidentyfikować innowacyjne podejścia do inwestycji społecznych na szczeblu krajowym i regionalnym w 28 państwach członkowskich oraz pozwolić na pogłębioną ocenę studiów przypadku przeprowadzoną w 10 państwach członkowskich. Szczególną uwagę zwrócono na ramy prawne i regulacyjne wymagające innowacji w zakresie polityki społecznej oraz różne podejścia do finansowania polityki i pomocy społecznej, w tym potencjalną rolę organizacji sektora publicznego i sektora prywatnego.

W projekcie inwestycje społeczne zostały zdefiniowane jako:

Inwestycje, które są postrzegane jako sprzyjające poprawie perspektyw dla przyszłej partycypacji w życiu gospodarczym i społecznym. Nacisk kładzie się na inwestycje w ludzi w celu zwiększenia ich produktywnych zdolności i sprzyjania długoterminowemu rozwojowi gospodarczemu. Inwestycje społeczne determinują politykę społeczną, a nacisk kładziony jest na długoterminowe korzyści dla społeczeństwa. Inwestycje socjalne zostały ukształtowane jako odpowiedź na obecne wyzwania społeczno-gospodarcze. Formy i fazy rozwoju inwestycji społecznych różnią się w poszczególnych krajach. Z przyczyn historycznych, politycznych, gospodarczych i kulturowych inwestycje społeczne są typowo krajowymi lub regionalnymi rozwiązaniami dla globalnych wyzwań2 ${ }^{2}$

Pomimo deklaracji o ograniczonym zasięgu, regionalnej, narodowej specyfice inwestycji społecznych, efektem zadania szóstego było wskazanie ponadnarodowych uwarunkowań innowacji mających kluczowe znaczenie w formułowaniu europejskich megatrendów. Celem niniejszego artykułu jest odpowiedź na pytanie: Na ile projektowanie innowacji społecznych i przewidywanie trendów społecznych na poziomie ponadnarodowym jest działaniem efektywnym? Efektywność społeczna w tym wypadku pojmowana będzie jako możliwość skutecznej, przynoszącej oczekiwane, społeczne skutki kreacji takich samych rozwiązań dla wszystkich państw członkowskich Unii Europejskiej (UE), w oparciu o takie same przewidywania (trendy).

\section{Cele projektu InnoSi. Plan realizacji zadania szóstego}

W zadaniu szóstym projektu nie zakładano tworzenia konkretnych innowacji społecznych, sprowadzało się ono jedynie do pierwszej fazy cyklu życia innowacji społecznej: inspiracji lub pomysłu. Pozostałe trzy fazy: sformułowania prototypu i pilotażu, implementacji oraz skalowania (dystrybucji modelu) pozostawały poza obszarem badawczym. Faza pierwsza jest o tyle ważna w całym procesie, że jest to nie tylko czas eksploracji i zbierania inspiracji, sygnałów, ale także podjęcia decyzji, które pomysły przejdą do fazy prototypu.

To właśnie proces podejmowania decyzji, nakreślenie obszarów, w jakich zbierano sygnały, a następnie wybór tych najsilniejszych oraz ich merytoryczna analiza budzą

${ }^{2}$ H. Jalonen et al., From Signals to Future Stories. A Handbook for Applying Foresight in the field of Welfare, Turku 2016, s. 9. 
największe wątpliwości autorki. Mimo że sygnały zbierane były lokalnie (chociaż najczęściej dotyczyły ogólnopaństwowych rozwiązań i reform), a trendy opisywane były przez członków zespołu projektowego pochodzącego z danego państwa członkowskiego, to megatrendy na poziomie ponadnarodowym formułowane były przez kierujący zadaniem zespół fiński. Co więcej, zespół pochodzący z jednego państwa członkowskiego wyznaczył także obszary tematyczne, w ramach których zbierane miały być sygnały. Można stwierdzić, że sam fakt narzucenia obszarów do poszukiwania innowacji zdeterminował efekt końcowy tej części zadania w postaci listy trendów. Wpływ doboru obszarów tematycznych oraz syntezy i kategoryzacji pozyskanych sygnałów zostanie poddany głębszej analizie w następnym podrozdziale.

Najważniejsze cele całego projektu zdefiniowane zostały jako:

- Opracowanie optymalnego modelu dystrybucji kosztów i korzyści, włączając te pozafinansowe.

— Identyfikacja efektywnych sposobów inwestycji publicznych, zwłaszcza w zakresie usług publicznych.

- Identyfikacja skutecznych środków uzupełniających inwestycje publiczne poprzez wkład sektora prywatnego oraz trzeciego sektora (z uwzględnieniem aspektów praw socjalnych).

- Dostarczenie wiedzy na temat przyszłych technik myślenia (opracowanych głównie dla biznesu), które można zastosować w prognozowaniu potrzeb i wdrażaniu innowacyjnych inwestycji społecznych w XXI w. ${ }^{3}$

Realizacji ostatniego ze wskazanych celów służyć miały wyniki uzyskane w zadaniu szóstym. Pierwszym etapem realizacji zadania było zbieranie sygnałów lokalnych. W tym celu zespoły projektowe rekrutowały 10-15 osób (pracownicy naukowi, studenci, osoby zorientowane społecznie) do skanowania sygnałów lokalnych. Osoby pozyskujące sygnały wzięły udział $\mathrm{w}$ wirtualnych sesjach treningowych. Obszary tematyczne sygnałów lokalnych podane przez fiński zespół projektowy to: rodzicielstwo i wychowywanie dzieci; starzenie się i seniorzy; imigracja i uchodźcy; ekonomia i rynek pracy. Nie ograniczono źródeł pozyskiwania sygnałów. Rekomendowano gromadzenie informacji w trakcie codziennej obserwacji. Można było je pozyskiwać z mass mediów, mediów społecznościowych, konferencji, książek, dyskusji ze studentami, rozmów ze znajomymi, ekspertami, poprzez przysłuchiwanie się rozmowom innych i prowadzenie obserwacji bezpośredniej. Oprócz perspektywy stricte lokalnej sygnały mogły dotyczyć kwestii ogólnonarodowych czy europejskich.

Następnie zespół projektowy danego państwa członkowskiego dokonał identyfikacji najmocniejszych, powtarzających się sygnałów (wskazano także na słabe trendy oraz zidentyfikowano trendy nieskorelowane z podanymi obszarami) oraz ich kategoryzacji, formułując listę trendów zdefiniowanych w projekcie jako zmiany w zachowaniach, postawach i wartościach w skali lokalnej i globalnej. W tym miejscu warto wspomnieć, że polski zespół zbierający innowacyjne sygnały wskazał na trend określany w projekcie jako „biały” - nieskorelowany z podanymi obszarami. Dotyczył on dokonującej się w owym

\footnotetext{
${ }^{3}$ InnoSi, The InnoSi objectives, http://innosi.eu/about-innosi (dostęp: 11 kwietnia 2017).
} 
czasie liberalizacji ustawodawstwa polskiego umożliwiającego produkcję genetycznie modyfikowanej żywności oraz pasz. Zjawisko to nie znalazło jednak swego odzwierciedlenia w megatrendach, mimo że zmiana ustawodawstwa w Polsce była pokłosiem zmian w UE.

Na kolejnym etapie przewidziane było ustalenie megatrendów (zdefiniowanych w projekcie jako oddziałujące na wszystko i wszędzie), stąd potrzeba rekrutacji 15-30 ekspertów (pracowników naukowych, decydentów itp.). W celu wyłonienia megatrendów przeprowadzono badanie Delphi w formie kwestionariusza elektronicznego. Narodowe zespoły projektowe dokonały następnie syntezy trendów oraz stworzyły karty trendów.

Etap następny to konwersja - opracowanie scenariuszy na przyszłość na podstawie megatrendów. Realizacja tego zadania wymagała organizacji jednodniowego, eksperckiego warsztatu innowacji społecznych (Social Innovation Camp) w 10 państwach członkowskich. Podczas warsztatu w ciągu kolejnych dwóch dni, na podstawie wyników pracy ekspertów, zespół projektowy opracował narodowe scenariusze na przyszłość. Wyniki końcowe zadania szóstego objęły: raporty dotyczące czynników sprawczych dla innowacji społecznych, scenariusze na przyszłość oraz praktyczny przewodnik po innowacjach.

\section{Od przewidywania do praktyk socjalnych: planowanie scenariuszy — realizacja zadania}

Sygnały zbierane na poziomie lokalnym rejestrowane były w serwisie społecznościowym Pinterest służącym do kolekcjonowania treści wizualnych. W ten sposób 10 państw członkowskich UE uczestniczących w projekcie stworzyło „tablicę” innowacyjnych sygnałów. O wyborze medium społecznościowego, jako platformy kolekcjonowania innowacyjnych sygnałów, zdecydował koordynujący zadanie zespół fiński. Każdy użytkownik Pinteresta może przypiąć do swojej tablicy dowolne zdjęcie znalezione w Internecie. Ta formuła wymuszała na kolekcjonerach sygnałów lokalnych nie tylko zidentyfikowanie sygnału o innowacyjnym charakterze, ale również odnalezienie korespondującego obrazka. Dla mniej wprawionych poszukiwania adekwatnej wizualizacji stanowiły nie lada wyzwanie, zwłaszcza w przypadkach ilustrowania tych stricte lokalnych sygnałów (łatwiej było z sygnałami ogólnopaństwowymi opatrzonymi zazwyczaj w mediach obrazem). Dla autorki poszukiwanie obrazów było stratą czasu, tym bardziej że obserwując inne narodowe „tablice”, nie można się było oprzeć wrażeniu, że kolekcjonerzy sygnałów często w pierwszej kolejności kierowali się atrakcyjnością znalezionego obrazka, a następnie dopasowywali do niego sygnał.

Po analizie i syntezie sygnałów przez Finów, koordynatorów zadania, zaproszeni przez zespoły narodowe do współpracy eksperci zostali poproszeni o przeprowadzenie analizy trendów zidentyfikowanych na poziomie ponadnarodowym, w wyniku której możliwa byłaby odpowiedź na pytanie, na ile programy wynikające z trendów przyczynią się do kreowania pożądanej, przyszłej rzeczywistości (którą to rzeczywistość eksperci mieli kreować w następnej kolejności, podczas warsztatu). W tym celu wykorzystano metodę delficką, technikę ankiety wypełnianej elektronicznie. 
Eksperci otrzymali od zespołu fińskiego listę 12 megatrendów ${ }^{4}$.

1. Ułatwianie pracy w sektorze opieki i zwiększenie jej atrakcyjności dzięki zastosowaniu robotyki i nowych technologii.

Współcześnie państwa UE różnią się znacząco w zakresie posiadania i stosowania nowych technologii, także w obszarze medycyny i opieki. To właśnie dostęp do technologii jest jednym z wyznaczników „Europy różnych prędkości”. Zgromadzone przez polski zespół sygnały o innowacjach społecznych w tym zakresie nie wskazywały na obecność technologicznego trendu w sektorze opieki. Nawet jeśli w pozostałych 9 krajach sygnały te były silne, tak daleko idąca zmiana w Polsce nie jest realna w ciągu następnych 10 lat - zwłaszcza z uwagi na fakt, iż od blisko 10 lat w Polsce toczy się dyskusja o konieczności standaryzacji usług opiekuńczych (co nie wymaga takich nakładów, jak te na nowe technologie) i nadal jej nie wypracowano. Odwołanie do tego megatrendu nastąpi w podrozdziale o scenariuszu na przyszłość dla seniora.

2. Wykorzystanie technologii w komunikacji i relacjach społecznych.

Trend obecny w Polsce, jednak obok pozytywnych aspektów tego stanu rzeczy kolekcjonerzy sygnałów w Polsce odebrali także sygnały wskazujące na obawę przed digitalizacją życia społecznego, rodzinnego, której efektem bywa rozluźnienie więzi, rzadsze bezpośrednie kontakty.

3. Wspieranie umiejętności obywateli w zakresie technologii oraz kształcenie ustawiczne.

Mimo że znaczenie kształcenia ustawicznego jest często podkreślane w strategiach rozwojowych Polski oraz programach walki z bezrobociem, polski zespół nie odebrał podobnych sygnałów.

4. Uzupełnienie systemu opieki społecznej poprzez społeczną odpowiedzialność pracodawców.

Tzw. społeczna odpowiedzialność pracodawców (biznesu) nie jest w Polsce raportowana ani w sposób skuteczny (dający wymierne efekty) monitorowana. Takich sygnałów również nie było (co podkreślone zostało przez ekspertów w badaniu Delphi).

5. Zapewnienie rozwoju cyfryzacji na obszarach wiejskich; równy rozwój obszarów miejskich i wiejskich.

Ponownie mamy tu do czynienia ze zjawiskiem opisywanym w strategiach rozwojowych, co nie miało jednak przełożenia na innowacyjne sygnały.

6. Wspieranie samozatrudnienia i przedsiębiorczości, jak również deregulacji rynku pracy (redefiniowanie pracy).

Liczne sygnały zgromadzone w Polsce odnosiły się do deregulacji rynku pracy, zjawiska samozatrudnienia, jednak $\mathrm{w}$ ich negatywnym znaczeniu. Samozatrudnienie jest w Polsce postrzegane jako forma zatrudnienia dająca najmniejsze gwarancje i brak poczucia bezpieczeństwa.

7. Wspieranie integracji imigrantów poprzez społeczną odpowiedzialność biznesu.

\footnotetext{
4 Trendy opisane zostały i udostępnione ekspertom w elektronicznym kwestionariuszu Delphi.
} 
Brak sygnałów w tym zakresie z uwagi na znikomą, stricte marketingową społeczną odpowiedzialność biznesu w Polsce oraz politykę rządu polskiego zamykającą granice przed imigrantami mogącymi mieć problemy z integracją.

8. Promowanie edukacji pozaformalnej oraz nowych form rozwoju, samorozwoju i rozwoju kompetencji.

Brak sygnałów.

9. Uzupełnienie systemu pomocy społecznej w oparciu o obserwację potrzeb prowadzoną w ramach oraz dla danej społeczności.

Funkcjonowanie systemu w oparciu o takie zasady wpisuje się z pewnością w polską ustawę o pomocy społecznej, nie zebrano jednak sygnałów z tego zakresu.

10. Wspieranie równości płci w życiu zawodowym i rodzinnym; zmiana ról płciowych.

11. Rozwój systemu urlopów rodzicielskich oraz opieki nad dzieckiem oparty na równości.

Do megatrendu nr 10 i 11 zaklasyfikowano liczne sygnały dotyczące programu Ministerstwa Rodziny, Pracy i Polityki społecznej 500+. Eksperci w badaniu delfickim podkreślili, iż program 500+ nie ma na celu wspierania równości płci w życiu zawodowym i rodzinnym (to nadal kobiety pełnią funkcje opiekuńcze).

12. Deregulacja i wzrost elastyczności rynku pracy.

Podobnie jak w przypadku trendu 6, w Polsce odebrano sygnały wskazujące na negatywne postrzeganie uelastyczniania rynku pracy.

Jak zostało to już podkreślone, przy analizie poszczególnych megatrendów eksperci podczas badania zwracali uwagę na niewłaściwą interpretację na poziomie ponadnarodowym sygnałów zebranych przez polski zespół. Uwagi ekspertów nie miały jednak, jak się później okazało, przełożenia na następne etapy realizacji zadania - planowanie scenariuszy oraz napisanie raportu/przewodnika po prognozowaniu dobrostanu.

Kolejny etap realizacji zadania zakładał organizację zgrupowania/warsztatu ekspertów. Polski zespół projektowy został wyposażony w następujące narzędzia, które następnie udostępnił ekspertom:

- Fabułę, która opisuje rozwój każdego scenariusza od dnia dzisiejszego do określonego punktu w przyszłości.

- Praktyczny przewodnik po prognozowaniu dobrostanu.

- Praktyczny przewodnik dotyczący zastosowania przyszłych technik myślenia $\mathrm{w}$ prognozowaniu kwestii dobrobytu, opublikowany na stronie projektu.

Koordynatorzy projektu, na podstawie wyników badania metodą delficką, zidentyfikowali siły napędowe wspólne dla wszystkich obszarów tematycznych ${ }^{5}$ :

- społeczeństwo (wspólnoty, relacje, styl życia);

- technologia (digitalizacja, automatyzacja, robotyka, sztuczna inteligencja);

- ekonomia (konsumpcja, inwestycje, inflacja, korporacje transnarodowe);

- środowisko (zanieczyszczenia, źródła energii);

- polityka (konflikty, wojny, partie polityczne itp.);

- legislacja (prawo, konwencje międzynarodowe, petycje obywatelskie itp.);

${ }^{5}$ H. Jalonen et al., op. cit., s. 27. 
— etyka (społeczna odpowiedzialność, polaryzacja bogactwa itp.);

- demografia (migracje, zatrudnienie, kohorty wiekowe itp.).

Z uwagi na powyższe siły napędowe eksperci zostali poproszeni o „spojrzenie na świat i życie oczami Obywatela X", przyjmując perspektywę 10 lat. Rozważając jedną kartę trendu, eksperci wyobrażali sobie Obywatela X w tym (wykreowanym przez uczestników projektu) świecie. Następnie zapisywali swoje refleksje, koncentrując się na odpowiedziach na następujące pytania:

1. Jakie pragnienia związane $\mathrm{z}$ dobrostanem, możliwości i rozwiązania oferuje Obywatelowi $\mathrm{X}$ ten trend?

2. Jakiego rodzaju zagrożenia może z sobą wnieść ten trend w życie Obywatela X?

3. Jakiego rodzaju rozwiązania są potrzebne, żeby uniknąć tych zagrożeń?

Poproszono ekspertów o wyselekcjonowanie i zapisanie łącznie 10-15 refleksji oraz o rozważenie, czy przysłużą się one w przyszłości Obywatelowi X do realizacji pragnień, nowych możliwości i rozwiązań.

W dalszej części warsztatu eksperci skupili się na budowaniu futurystycznej historii Obywatela X. Otrzymali oni szczegółową instrukcję dotyczącą przebiegu zadania. Mieli opowiedzieć futurystyczną historię jednego dnia z życia Obywatela X w roku 2027, zaczynając od poranka, a następnie umieścić swoje pomysły dotyczące przebiegu dnia w opisie. Eksperci w swym opisie powinni byli uwzględnić wszystkie wyselekcjonowane uprzednio innowacje. Po wykreowaniu całej historii dnia, od rana do wieczora, eksperci poproszeni zostali o ponowne przemyślenie, czy udało im się wprowadzić nowe rozwiązania, z których Obywatel X będzie mógł skorzystać, budując swój dobrostan. Pomysły na wykorzystanie zaproponowanych rozwiązań powinny również stanowić ważny element tworzonej historii. Dodatkowo poproszono ekspertów o przedyskutowanie i zapisanie tego, co się zmieniło w codziennym życiu Obywatela X w roku 2027. Jakie siły napędowe mogą się potencjalnie przyczynić do realizacji tego scenariusza? Jakie przeszkody mogą stanąć na drodze do jego urzeczywistnienia?

Profile obywateli podane przez zespół fiński były następujące: senior (71 lat); imigrant (28 lat); NEET (Not in Employment, Education or Training) 19-latka pozostającą poza sferą zatrudnienia i edukacji; 40-letnia pracująca matka; 11-letnia uczennica, azylantka z Iraku. W celu zaprezentowania procesu projektowania na przyszłość: od aktualnego profilu obywatela, poprzez zaplanowanie scenariusza na przyszłość, po ustalenie trendów, wybrany został jeden profil obywatela. Wybór jednostki analizy nie był przypadkowy. Wybrano scenariusz ponadnarodowy, najbardziej odległy od tego, co udało się zidentyfikować i przewidzieć polskiemu zespołowi odbierającemu sygnały oraz ekspertom.

\section{Scenariusz dla unijnego seniora}

Najbardziej kontrowersyjny dla polskich ekspertów okazał się być profil oraz scenariusz napisany na poziomie ponadnarodowym dla 71-letniego Williama. Wyjściowa sytuacja życiowa Williama: emerytowany elektryk mieszkający samodzielnie na przedmie- 
ściu, wdowiec, jego dzieci mieszkają daleko. Interesuje się sportem, swój stan zdrowia ocenia jako dobry, choć ma nadwagę i pojawiły się u niego pierwsze objawy choroby Alzheimera. Potrzeby i pragnienia Williama: lubi dzieci i chciałby pomagać rodzinom w okolicy; brakuje mu towarzystwa innych ludzi, np. wspólnego uczestnictwa w wydarzeniach sportowych. Zidentyfikowane wyzwania stojące przed seniorem: pogorszenie stanu zdrowia fizycznego i psychicznego, radzenie sobie w wypełnianiu codziennych obowiązków domowych, umierający przyjaciele i dystans dzielący go od członków rodziny (samotność), brak kompetencji informatycznych.

A oto scenariusz, jaki zaplanowano dla Williama na poziomie ponadnarodowym ${ }^{6}$. $\mathrm{W}$ dni powszednie William jada śniadanie $\mathrm{z}$ rodziną, która mieszka obok. Jest to rozwiązanie korzystne dla obu stron, ponieważ William dotrzymuje towarzystwa dzieciom sąsiadów, zanim te pójdą do szkoły. Dzieci lubią spędzać czas z Williamem, ponieważ opowiada im nie tylko o swoim życiu, ale także o wydarzeniach, które zrewolucjonizowały Europę. William utrzymuje kontakt $\mathrm{z}$ własną rodziną przede wszystkim wirtualnie, co jest łatwe dzięki nowoczesnym urządzeniom wykorzystującym sztuczną inteligencję i rozpoznawanie mowy. Dzieci Williama organizują cotygodniową kolację rodzinną przez Internet. Dzięki tak podtrzymywanej relacji dzieci i wnuki Williama mieszkające za granicą mogą znowu znaleźć się w ich starym domu.

Technologia ułatwia codzienne życie seniora. William jest trochę rozbawiony, kiedy przypomina sobie, że początkowo był przeciwny robotowi opiekuńczemu oferowanemu przez pielęgniarkę, ponieważ robot zapewnia niezrównaną pomoc $\mathrm{w}$ radzeniu sobie $\mathrm{w}$ domu. Zarządza jego lekami i przypomina o regularnych posiłkach oraz codziennych obowiązkach. William używa skanera w celu sprawdzenia wartości odżywczej posiłków. Jest także zaintrygowany usługą dostarczania posiłków przez drony na słabo zaludnionych obszarach.

William zawsze lubił sport. Kiedy był młodszy, grał w piłkę nożną, a teraz lubi ćwiczyć i oglądać sporty w telewizji. Bierze udział w cotygodniowej wirtualnej sesji ćwiczeń z innymi mężczyznami ćwiczącymi we własnych domach. Obraz i dźwięk w czasie rzeczywistym dają mu poczucie wspólnoty. William ma chorobę Alzheimera, ale nigdy nie przestaje zadziwiać swoich członków rodziny i przyjaciół pamięcią związaną z piłką nożną. Jego wnuki są dumne, że chociaż dziadek może zapomnieć, gdzie położył klucze do domu, to nigdy nie zapomina wyników sportowych.

William jest również członkiem kółka seniora w lokalnym klubie piłkarskim, sponsorowanym przez firmę transnarodową. Członkowie koła seniorów mają zapewniony transport z domu i do domu, a juniorzy pomagają im w cięższych obowiązkach domowych. Seniorzy mają wiele do opowiedzenia, dlatego też są mile widziani na imprezach klubowych.

William wie, że z biologicznego punktu widzenia nie zbliżył się nawet jeszcze do swego maksymalnego wieku. Leki hamujące Alzheimera zadziałały obiecująco i dały na nowo wiarę w przyszłość. Ta postawa została również wzmocniona poprzez rolę Williama w łączeniu przeszłych, obecnych i przyszłych pokoleń.

${ }^{6}$ Ibidem, s. 35-36. 
Dwa wyeksponowane trendy na przykładzie profilu seniora i zaplanowanego dla niego scenariusza:

1. Nowe technologie i różne urządzenia techniczne wykorzystywane w opiece nad seniorami spowodowały wzrost zainteresowania sektorem opieki wśród chłopców.

2. Seniorzy są coraz bardziej przekonani, że chociaż kwestie zdrowia idą w parze z postępującym wiekiem, to technologia i nowy rodzaj wspólnoty sprawiają, że zdolność osoby do działania coraz mniej zależna jest od wieku.

Przy planowaniu scenariuszy, ergo przewidywaniu trendów, autorzy projektu zalecili uwzględnienie następujących zasad ${ }^{7}$ :

1. Wiara, że alternatywna przyszłość możne zostać zbadana w teraźniejszości.

2. Wyobrażenie, że myślenie przyszłościowe jest zdolnością, którą można rozwijać i wzmacniać.

3. Rozpoznanie instytucjonalnych i historycznych trajektorii, które kształtują krajobraz polityczny.

4. Identyfikacja i definiowanie natury problemów związanych z zakresem wiedzy (niepewność, złożoność, niejednoznaczność).

5. Usprawnienie swego przewidywania dzięki wykorzystaniu sprawdzonych metod $\mathrm{w}$ celu rozwiązania różnych problemów związanych z zakresem wiedzy.

6. Zapewnienie różnorodności osób i metod w celu identyfikacji nowych sygnałów.

7. Zrozumienie sygnałów poprzez wykorzystanie różnych technik (indukcyjnych, dedukcyjnych, intuicyjnych), a następnie klasyfikacja sygnałów w znaczące trendy.

8. Koncentracja na nowych możliwościach.

9. Wykorzystywanie możliwości poprzez angażowanie odpowiednich interesariuszy i współtworzenie z nimi scenariuszy na przyszłość.

W ramach opisywanego projektu trudno jest dokonać ewaluacji zastosowania zasad 5, 6, 7 oraz 9, autorzy nie przedstawili bowiem aż tak wnikliwego opisu metodologicznego, stąd też nie wiadomo, z jakich konkretnie źródeł pozyskiwane były sygnały i jakimi technikami były następnie analizowane, czy też jakie źródła i techniki były przez uczestników zadania najczęściej wykorzystywane. Przedstawiony profil obywatela wraz z zaprojektowanym scenariuszem na przyszłość pozwala natomiast stwierdzić, iż w odniesieniu do sytuacji w Polsce lub szerzej — w krajach „mniejszej prędkości” rozpoznanie instytucjonalnych i historycznych trajektorii kształtujących sytuację polityczną oraz identyfikacja problemów związanych z zakresem wiedzy zostały obarczone błędem.

Wydaje się, że oprócz barier realizacji konkretnego, zaplanowanego scenariusza warto wskazać także na ograniczenia natury bardziej ogólnej związane z procesem innowacji. Inny zespół projektowy, również prowadzący badania na poziomie ponadnarodowym ${ }^{8}$, do takich ograniczeń zaliczył: wyzwania związane z brakiem środków finansowych

7 Ibidem, s. 38.

8 Zespół prowadzący badania w 7. Programie ramowym Komisji Europejskiej (2014), zrzeszający 6 instytucji europejskich: Duński Instytut Technologiczny, Wrocławskie Centrum Badań EIT+, Centrum Inwestycji Społecznych Uniwersytetu w Heidelbergu, Organizację Badawczą Atlantis, Katolicki Uniwersytet w Portugalii, The Young Foundation. 
i niefinansowych; trudności z przyjęciem otwartego modelu innowacji, wyzwania związane z pomiarami; ograniczenia podmiotów wdrażających innowacje (brak możliwości i kompetencji $)^{9}$.

W tym badaniu inaczej także zidentyfikowano (choć nie zawsze inne) obszary problemowe, pozostające wyzwaniem dla rządów i wspólnot w całej Europie. Te obszary to: bezrobocie, ubóstwo dzieci i rosnące nierówności. Do nowych wyzwań zaliczono migracje i ich następstwo - wysoce zróżnicowane społeczności wymagające działań na rzecz spójności społecznej oraz dodatkowych nakładów na usługi lokalne. Podkreślono też kwestię starzejącej się populacji, które to zjawisko zwiększa wymagania dotyczące usług zdrowotnych i opieki. Zasygnalizowano, bliżej niezdefiniowane, nowe style życia, których konsekwencją są problemy z otyłością i wzrostem chorób przewlekłych ${ }^{10}$.

Natomiast $\mathrm{w}$ kontekście negatywnych sił sprawczych zwrócono przede wszystkim uwagę na kryzysy finansowe, zwłaszcza kryzys w finansach publicznych skutkujący ograniczeniami w usługach publicznych oraz towarzyszącymi im programami oszczędnościowymi w Europie i poza nią, które pogłębiały wiele ze zidentyfikowanych tendencji. Autorzy zauważyli jednocześnie, że te niekorzystne zmiany pobudziły zainteresowanie innowacjami oraz wdrażanie innowacji społecznych w celu wypełnienia powstałej luki. Powołano się na przykład Barcelony, której mieszkańcy doświadczeni kryzysem finansowym zaczęli angażować się w niekapitalistyczne praktyki gospodarcze (spółdzielnie konsumenckie, sieci wymiany, bezpłatne uniwersytety). Inicjatorami tych rozwiązań są zwykli obywatele reagujący twórczo i innowacyjnie na pilne wyzwania, których oni i ich społeczności doświadczają ${ }^{11}$.

Po uwzględnieniu tak definiowanych obszarów problemowych oraz negatywnych sił sprawczych kształtujących społeczne i gospodarcze tendencje (trendy) w zaprezentowanym scenariuszu dla seniora należałoby dokonać znacznych zmian. Urealnienie sytuacji wyjściowej poskutkuje bowiem urealnionym scenariuszem na kolejne 10 lat. W innowacjach społecznych nie chodzi bowiem o marzenia (a do takiej kategorii często odwołują się autorzy projektu InnoSi), lecz o wyobraźnię, która pozwala na kreatywne, innowacyjne rozwiązywanie problemów. Innowacyjne inwestycje społeczne to, posługując się dużym skrótem myślowym, rozwiązanie kryzysowe, mające na celu odciążenie sektora publicznego, kolejna próba implementacji wielosektorowej polityki społecznej wzbogaconej dodatkowo o samopomoc i bezpośrednie zaangażowanie jednostek. W tym kontekście postinnowacyjne scenariusze zaproponowane przez fiński zespół projektowy jawią się jako fantasmagorie, a nie propozycje rzeczywistych (choć alternatywnych) rozwiązań.

9 Social Innovation Theory and Research. A Guide for Researchers, https://iupe.files.wordpress.com/ 2015/11/tepsie-research_report_final_web.pdf (dostęp: 22 kwietnia 2017).

10 Ibidem.

11 Ibidem. 


\section{Podsumowanie}

Zaprojektowane na poziomie ponadnarodowym innowacyjne inwestycje społeczne okazały się nieprzystające do rzeczywistości „europejskich państw mniejszej prędkości”, w tym Polski. Przyczyn tego stanu rzeczy upatrywać można w zastosowaniu niewłaściwej metodologii, której efektem był nietrafny, nierzetelny pomiar, lub w zbyt daleko idącej syntezie sygnałów pochodzących z 10 różnych pod względem politycznym, kulturowym, a nade wszystko rozwojowym państw. Wydaje się, iż właśnie owo syntetyczne podejście miało decydujący wpływ na wynik zadania.

W tym miejscu dotykamy ważnego problemu zarządzania w UE: Czy źródło finansowania musi być jednocześnie centrum projektowo-decyzyjnym? Taka konwencja z pewnością sprzyja zarządzaniu w wielu obszarach, zaprezentowany przykład świadczy jednak o tym, iż polityka społeczna się weń nie wpisuje. Karkołomną okazała się próba unifikacji oddolnych sygnałów celem znalezienia wspólnego mianownika dla procesów społecznych (trendów), a następnie na tej podstawie projektowanie konkretnych rozwiązań.

Efektywność zadania wzrosłaby, gdyby zespół projektujący w wymiarze ponadnarodowym wsłuchał się w sygnały pochodzące ze społeczeństw poszczególnych państw członkowskich. W tych sygnałach obecne są bowiem wszystkie istotne zmienne, które powinny być wzięte pod uwagę $\mathrm{w}$ procesie projektowania inwestycji społecznych: kultura polityczna, zakres partycypacji, wartości społeczne (zjawiska definiujące model społeczeństwa obywatelskiego) oraz poziom rozwoju społeczno-gospodarczego. Sygnały zebrane przez zespół polski, a następnie propozycje rozwiązań zgłaszane przez polskich ekspertów były mocno osadzone w polskiej rzeczywistości.

Dysponujemy efektywnymi mechanizmami ewaluacji wydatkowania pieniędzy pochodzących z funduszy unijnych. Należy do nich pomiar skuteczności (relacja celów zamierzonych do celów osiągniętych), ekonomiczności (stosunek poniesionych nakładów do osiągniętych efektów) oraz efektywności, która oznacza skuteczność w osiąganiu celów przy zachowaniu mechanizmów racjonalizacji wydatkowania środków publicznych ${ }^{12}$. Implementacja zaproponowanych ponadnarodowych rozwiązań w Polsce, z opisanych uprzednio przyczyn, nie byłaby skuteczna ani ekonomiczna. Dlatego, również z tych względów, zasadnym jest, aby cały proces projektowania inwestycji społecznych przebiegał w oparciu o potrzeby i możliwości danego państwa członkowskiego.

\section{Bibliografia}

InnoSi, The InnoSi objectives, http://innosi.eu/about-innosi (dostęp: 11 kwietnia 2017).

Jalonen H. et al., From Signals to Future Stories. A Handbook for Applying Foresight in the Field of Welfare, Turku University of Applied Sciences, Turku 2016.

Nowa koncepcja polityki regionalnej. Wnioski z prac tematycznych grup roboczych, Ministerstwo Rozwoju Regionalnego, Warszawa 2008.

12 Nowa koncepcja polityki regionalnej. Wnioski z prac tematycznych grup roboczych, Warszawa 2008. 
Social Innovation Theory and Research. A Guide for Researchers, Theoretical, Empirical and Policy Foundations for Social Innovation in Europe (TEPSIE) 2014, https://iupe.files.wordpress.com/2015/11/tepsie-research_report_final_web.pdf (dostęp: 22 kwietnia 2017).

\section{Designing innovative social investment at the supranational level}

Keywords: innovative social investments, effectiveness of social projects, transnational social policy

\section{Summary}

In this paper, social innovations are presented from the perspective of the project Innovative Social Investment: Strengthening communities in Europe, InnoSI, No 649189. The project has been implemented within the framework of the program: Horizon 2020-EU.3.6. The study was intended to identify innovative approaches to social investment at national and regional level in $28 \mathrm{EU}$ Member States, with in-depth case studies conducted in 10 Member States. The purpose of this article is to answer the question: whether designing social innovations and anticipating social trends at transnational level is an effective measure. 